\title{
Temperature-regulated expression of outer membrane proteins in Shigella flexneri
}

\author{
Hemavathy Harikrishnan ${ }^{1}$, Asma Ismail ${ }^{2,3}$ and Kirnpal-Kaur Banga Singh ${ }^{1 *}$
}

\begin{abstract}
Background: Bacteria exist widely in a diversity of natural environments. In order to survive adverse conditions such as nutrient depletion, biochemical and biological disturbances, and high temperature, bacteria have developed a wide variety of coping mechanisms. Temperature is one of the most important factors that can enhance the expression of microbial proteins. This study was conducted to investigate how outer membrane proteins (OMPs) of the bacterium Shigella flexneri respond to stress, especially during fever when the host's body temperature is elevated.

Methods: OMPs of S. flexneri ATCC 12022 and clinical isolate SH057 were extracted from an overnight culture grown at $37,38.5$, and $40^{\circ} \mathrm{C}$. Comparisons of the expressed proteins under the different growth conditions were based on equal numbers of bacterial cells loaded in the SDS-PAGE gels. Separated proteins were stained with Coomassie brilliant blue. Selected proteins showing increased expression at 38.5 and $40^{\circ} \mathrm{C}$ were characterized by performing MALDI-ToF-ToF.
\end{abstract}

Results: Different degrees of expression were demonstrated for different proteins expressed at $37^{\circ} \mathrm{C}$ compared to 38.5 and $40^{\circ} \mathrm{C}$. The proteins with molecular sizes of 18.4, 25.6, and $57.0 \mathrm{kDa}$ showed increased expression level at increasing temperature and were identified as Dps, WrbA, and PepA, respectively.

Conclusion: This study revealed that strains of $S$. flexneri respond at the proteomic level during stress caused by elevated temperature by decreasing the expression of proteins, maintaining the level of important proteins, or enhancing the levels of proteins presumably involved in survival and virulence.

\section{Introduction}

Bacillary dysentery (also known as shigellosis) caused by Shigella spp. is a public health concern in developing countries and for travelers from industrialized nations [1]. The annual numbers of shigellosis episodes and deaths in Asia were estimated to be 91 million and 414,000, respectively, with $S$. flexneri and $S$. sonnei being the first and second most common serotypes [2]. A 9-year retrospective study conducted in Northeast Malaysia [3] showed that the isolation rate is $9.99 \%$ of the total bacterial pathogens isolated from stool specimens, with S. sonnei and S. flexneri being the most common species isolated Shigellosis causes diarrhea or dysentery with frequent mucoid bloody stools, abdominal cramps, and fever [4]. The presentation of these

\footnotetext{
* Correspondence: kiren@kck.usm.my

'Department of Medical Microbiology \& Parasitology, School of Medical Sciences, Health Campus, Universiti Sains Malaysia, 16150 Kubang Kerian, Kelantan, Malaysia

Full list of author information is available at the end of the article
}

clinical symptoms is due to the invasion and growth of the bacterium in the intestinal mucosal cells. The bacterium subsequently causes cell death and spreads laterally to infect and kill the adjacent epithelial cells. This mechanism can lead to mucosal ulceration, inflammation, and bleeding [5]. The life-threatening complications caused by shigellosis include metabolic derangements, such as dehydration, hyponatraemia, hypoglycaemia, hypoproteinaemia, and severe anorexia, as well as intestinal complications such as toxic megacolon, rectal prolapse, and intestinal perforation [6,7]. Bacteraemia due to Shigella is relatively rare but does occur $[8,9]$.

The outer membrane of Gram negative bacteria plays many roles in cellular function in addition to the classical role of transporting ions through the porin proteins [10]. Protective immunity elicited by outer membrane proteins (OMPs) has been documented for several Gram negative organisms [11]. During the course of infection, growth of bacteria is influenced by various environmental factors, 
including $\mathrm{pH}$, osmotic strength, oxygen, iron availability, and temperature, which may change dramatically. Thus, the bacteria must adapt to and survive in the new environment [12]. Hale (1991) found that some temperaturesensitive Shigella spp. are capable of invading the intestinal epithelium only at elevated temperature and that invasion does not take place at $37^{\circ} \mathrm{C}$ [13]. Ellis (1996) reported that certain proteins are overexpressed in response to high temperature (e.g., heat shock proteins (HSPs) and serve as defense mechanisms against various environmental stresses [14]. Research has also shown that the HSPs are usually related to the virulence of the pathogens [15].

In this study, we compared the OMP expression profiles of $S$. flexneri cells grown at $37,38.5$, and $40^{\circ} \mathrm{C}$ to evaluate expression level changes in cells that are induced by temperature increase. Those proteins that showed a prominent increase in expression at 38.5 and $40^{\circ} \mathrm{C}$ were subsequently identified using MALDI-ToF-ToF analysis in order to demonstrate the presence of HSPs.

\section{Materials and methods}

\section{Shigella strains and the sereny test}

The four clinical strains (SH052, SH057, SH060, and SH062) of Shigella flexneri 2a used in this study were obtained from the Department of Medical Microbiology and Parasitology, School of Medical Sciences, Universiti Sains Malaysia. Virulence of these isolates was checked by performing Sereny test in order to determine their ability to cause keratoconjunctivitis in guinea pigs. This animal study was conducted in accordance with the requirements of the Animal Ethics Committee, Universiti Sains Malaysia (AECUSM) approval protocol PPSG/07(A)/044.

The four S. flexneri strains were tested via inoculation into guinea pig eyes as follows. The bacterial strains were grown overnight in LB broth. They were used for the test when they reached $10^{8} \mathrm{CFU}$ in normal saline $(0.9 \%)$, as determined by measuring optical density (OD) at $600 \mathrm{~nm}$. Each eye of a Hartley guinea pig $(n=6)$ was inoculated in the conjunctival sac with $10^{8} \mathrm{CFU}$ of one of the wild strains. Guinea pigs were examined daily for 5 days, and their inflammatory responses were graded according to Hartman et al. [16]. Development of the disease was rated as follows: 0 : no disease or mild; 1 : mild conjunctivitis or late development and/or rapid clearing of symptoms; 2 : keratoconjunctivitis without purulence; and 3: fully developed keratoconjunctivitis with purulence. Among the four strains, SH057 caused fully developed keratoconjunctivitis with purulence in guinea pigs and thus was used in this study. A reference strain, S. flexneri ATCC 12022, was the standard organism used when performing protein profiling in this study.

S. flexneri ATCC 12022 and the clinical isolate were maintained in nutrient slants agar and Tryptic soy broth containing $20 \%$ glycerol. Working cultures were prepared by inoculating one single colony in $10 \mathrm{ml}$ of nutrient broth, which was then incubated overnight at $37^{\circ} \mathrm{C}$ with shaking at $200 \mathrm{rpm}$ in an orbital shaker (Forma Orbital Shaker, Model-420, USA). The purity of the culture was determined by inoculating it on blood agar. The identities of both S. flexneri ATCC 12022 and the clinical isolate were confirmed by performing standard biochemical identification using triple sugar iron agar, sulfide-indole motility medium, urease, methylene red, and citrate.

\section{Outer membrane protein (OMP) preparation}

S. flexneri ATCC 12022 and clinical isolate SH057 were grown overnight in nutrient broth at $37,38.5$, and $40^{\circ} \mathrm{C}$ under shaking at $200 \mathrm{rpm}$ in separate orbital shakers (Forma Orbital Shaker). Preparation of the OMPs expressed at the three temperatures was performed following the published procedure for extracting OMPs of Salmonella typhi [17]. Cells were harvested by centrifugation at $15,900 \mathrm{x}$ g for 18 minutes and resuspended in $8 \mathrm{ml}$ of $0.01 \mathrm{M}$ HEPES (N-2 hydroxy ethyl piperazineN'-2ethane sulfonicacid) buffer ( $\mathrm{pH}$ 7.4). This suspension was then mixed with $8 \mu \mathrm{l}$ of $10 \mathrm{mM}$ DNAse (Sigma, USA), $8 \mu \mathrm{l}$ of $10 \mathrm{mM}$ RNAse (Sigma, USA), and $800 \mu \mathrm{l}$ of $100 \mathrm{mM}$ phenylmethylsulfonyl fluoride (Calbiochem, USA). Bacterial cell in the suspensions were disrupted by vortexing (HeidolphReax Top, Germany) with glass beads $(\sim 0.2 \mathrm{~mm}$ in diameter, BDH Chemical Ltd., UK) for 1.5 hours, with 1 minute alternate on ice until 95\% lysis was achieved. Cell disruption was confirmed using the Gram staining method. The cell lysate obtained was aspirated and the glass beads were washed with $0.01 \mathrm{M}$ HEPES buffer until the cell turbidity was clear. The unlysed cells were removed by centrifugation using a high-speed refrigerated centrifuge (Kubota, Model 6930, Japan) at $7,800 \times \mathrm{g}$ at $4^{\circ} \mathrm{C}$ for 15 minutes. The supernatant was then centrifuged with an ultracentrifuge (Hitachi, Model CP $80 \mathrm{MX}$, Japan) at $145,100 \times \mathrm{g}$ at $4^{\circ} \mathrm{C}$ for 1 hour (using rotor type P40 ST) to obtain crude cell envelopes. The Triton X-100 extraction method was used to separate the inner and outer membranes. The pellet containing the crude envelopes was treated with 0.01 M HEPES containing 4\% Triton X-100 (Bio-Rad, USA) to solubilize the inner membrane. The mixture was incubated at room temperature for 10 minutes. The insoluble OMPs were pelleted using the ultracentrifuge at $181,800 \times \mathrm{g}$ at $4^{\circ} \mathrm{C}$ for 1 hour (using rotor type P55 ST2). The pellet was resuspended with $4 \mathrm{ml}$ of $30 \mathrm{mM}$ Tris $-\mathrm{HCl}, \mathrm{pH} 8.0$ and stored at $-20^{\circ} \mathrm{C}$ until use.

\section{Profiling of the OMP(s) of S. flexneri using SDS-PAGE}

SDS-PAGE was used to determine the protein profiles of $S$. flexneri. Proteins were separated on $10 \%$ polyacrylamide gel with a $4 \%$ stacking gel on top. Approximately $30 \mu \mathrm{g}$ of OMPs from S. flexneri ATCC 12022 and clinical 
isolate $\mathrm{SH} 057$ expressed at $37,38.5$, and $40^{\circ} \mathrm{C}$ were loaded in each well and profiled using PROTEAN II xi (Bio-Rad). The OMPs obtained were resuspended with sample buffer containing $0.1 \%$ SDS and 2 - $\beta$-mercaptoethanol $(10 \%)$, heated at $100^{\circ} \mathrm{C}$ for 10 minutes, and electrophoresed at room temperature at constant current (30 mA) for 4 hours. The OMP profiles of S. flexneri were observed via SDS-PAGE gels stained with Coomassie brilliant blue (Bio-Rad). Molecular weight protein standards (Amersham, UK) were used for molecular weight determination. The molecular weights of OMPs were determined from the SDS-PAGE gels using an image analyser (SYNGENE Bio Imaging System, Japan).

\section{MALDI-ToF-ToF Mass Spectrometry}

Three protein bands (18.4, 25.6, and $57.0 \mathrm{kDa}$ ) that showed a prominent increase in expression at $40^{\circ} \mathrm{C}$ were identified by performing MALDI-ToF-ToF. The OMPs of SH057 were resolved on 10\% SDS-PAGE gel using the Mini PROTEAN 3 system (Bio-Rad). Approximately $100 \mu \mathrm{g}$ of OMPs were loaded for the preparative comb gel (Bio-Rad). The gel was stained with Coomassie brilliant blue R220 to visualize the protein profile. The targeted protein bands were carefully excised from the preparative gel with a surgical blade as a narrow sharp band to avoid background contamination. The excised protein bands were kept in sterile $1.5 \mathrm{ml}$ tubes and sent to Proteomics International Pty Ltd. (Nedlands, Western Australia) for further analysis. Briefly, the protein samples were first digested with mass spectrometry grade trypsin, and the peptides were extracted according to standard techniques. The protein bands were subjected to mass spectrometry analysis in which the peptides were analysed using a MALDI-ToF-ToF mass spectrometer (ABI 4800 instrument). The identified peptide fragments were searched against Mascot, Matrix Science (http:// www.matrixscience.com). The search parameters were as follows: trypsin digestion with one missed cleavage; carbamidomethyl modification of cysteine as a fixed modification and oxidation of methionine as a variable modification; peptide tolerance, \pm 0.6 ; MS/MS tolerance, \pm 0.6 ; peptide charge, $1+$; monoisotopic mass.

\section{Results}

The OMP profiles of S. flexneri ATCC 12022 and clinical isolate $\mathrm{SH} 057$ expressed at $37,38.5$, and $40^{\circ} \mathrm{C}$

Figure 1 shows the OMP profiles of ATCC 12022 and clinical isolate $\mathrm{SH} 057$ expressed at $37,38.5$, and $40^{\circ} \mathrm{C}$. OMPs were detected in both strains at the tested temperatures, and a total of 24 protein bands were observed in the SDS-PAGE (Table 1). Sixteen protein bands were expressed by both strains at the three temperatures tested. Of the 24 bands, $75 \%$ were present in ATCC 12022 and $88 \%$ were observed in $\mathrm{SH} 057$ at 37 and $38.5^{\circ} \mathrm{C}$.
At $40^{\circ} \mathrm{C}, 79 \%$ and $92 \%$ of the proteins were detected in ATCC 12022 and the clinical isolate, respectively. A unique protein band $(52.8 \mathrm{kDa})$ was expressed in both strains only at $40^{\circ} \mathrm{C}$. Five protein bands $(15.1,25.6,74.6$, 85.3 , and $88.2 \mathrm{kDa}$ ) were expressed by the clinical isolate at all three temperatures but were not expressed by ATCC 12022. Two protein bands (76.3 and $95.4 \mathrm{kDa})$ were only expressed by the ATCC strain at all three temperatures.

\section{Comparison of the expression levels of OMPs in S. flexneri ATCC 12022 and clinical isolate SH057}

The degrees of OMP expression in both strains at 38.5 and $40^{\circ} \mathrm{C}$ were compared to those at $37^{\circ} \mathrm{C}$ and were found to differ (Table 2). For example, the level of the $30.9 \mathrm{kDa}$ protein band was maintained in the ATCC strain at $40^{\circ} \mathrm{C}$ (same level of expression as seen in the $37^{\circ} \mathrm{C}$ ), whereas it showed increased expression in the clinical isolate. The level of the $57.0 \mathrm{kDa}$ protein band also was maintained in the ATCC strain at $38.5^{\circ} \mathrm{C}$, but it was decreased in the clinical isolate. However, this protein's expression was increased at $40^{\circ} \mathrm{C}$ in both strains. The expressions of the $18.4,30.9$, and $100.3 \mathrm{kDa}$ proteins were maintained at $38.5^{\circ} \mathrm{C}$ but up-regulated at $40^{\circ} \mathrm{C}$ in both strains. There also was a prominent increase in the expression of the $18.4 \mathrm{kDa}$ protein at $40^{\circ} \mathrm{C}$ in both strains. Overall, the majority of proteins in the clinical isolate were found to be up-regulated at $40^{\circ} \mathrm{C}$, whereas six proteins $(15.1,16.2,25.6,57.0,63.2$, and $85.3 \mathrm{kDa})$ showed decreased expression at $38.5^{\circ} \mathrm{C}$. Fourteen of the 18 proteins found in the ATCC strain were insensitive to the increased temperature.

The MALDI-ToF mass spectrometry analysis using Mascot (www. matrixscience.com) was performed to identify the proteins showing overexpression during heat stressed.

According to the Mascot search results obtained using the mass spectrometry database search engine, the $18.4 \mathrm{kDa}$ protein was a match for Dps (a DNA starvation/stationary phase protection protein) with a score of 537 with 4 matched peptides. A score of $>36$ indicates identity or extensive homology at a significant level $(\mathrm{p}<0.05)$. The $25.6 \mathrm{kDa}$ protein was a matched for PepA, and the $57.0 \mathrm{kDa}$ protein was a match for WrbA with only one matched peptide identified.

\section{Discussion}

Due to their location on the cell, OMPs have been shown to elicit host immune responses and hence are categorized as virulence factors [18]. During entry into a host, pathogenic bacteria may experience many types of stresses, such as those caused by changes in temperature, $\mathrm{pH}$, osmotic strength, and iron availability, and these factors greatly influence the growth of the pathogenic organisms. Temperature variation is one of the most important 


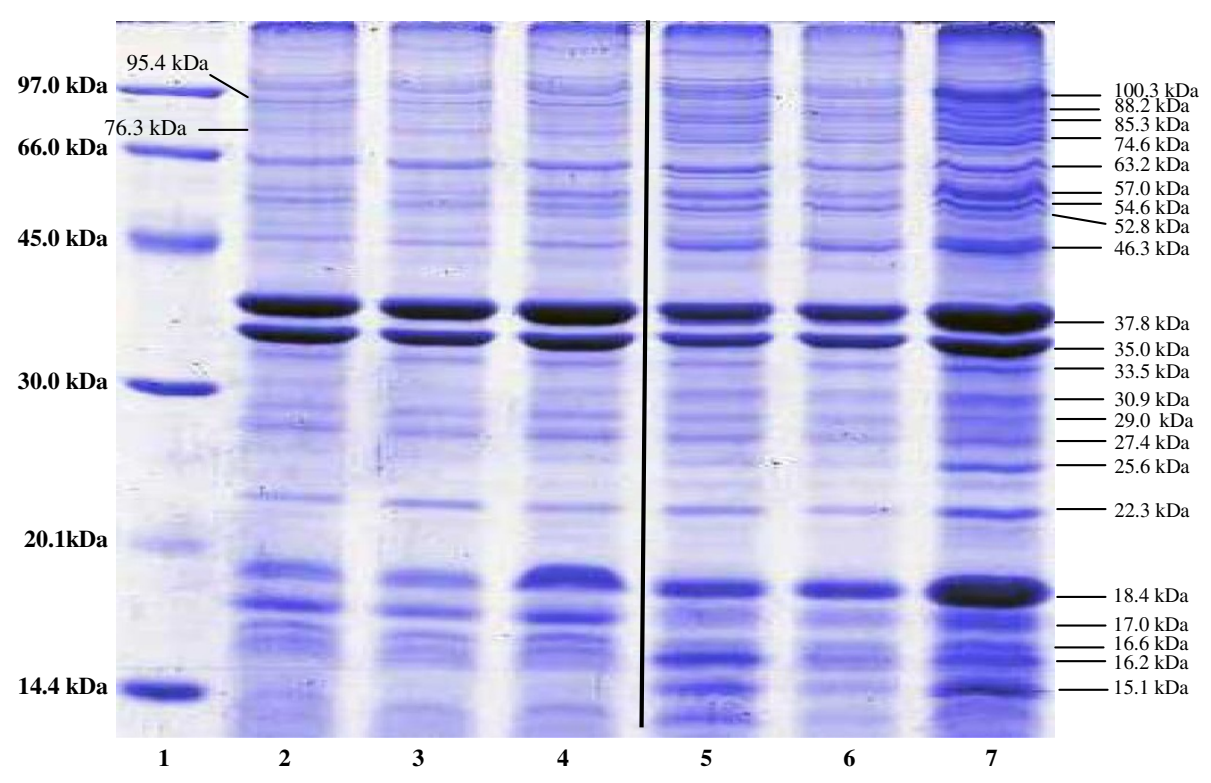

Figure 1 SDS-PAGE gel showing the outer membrane protein (OMP) profiles of S. flexneri ATCC 12022 and the clinical isolate SH057 at $37^{\circ} \mathrm{C}, 38.5^{\circ} \mathrm{C}$, and $40^{\circ} \mathrm{C}$.

stress factors that can be used to demonstrate the presence of heat shock OMPs in S. flexneri.

We conducted this study to determine how S. flexneri responds at the proteomic level to the stress of elevated temperature. When temperature was increased to $40^{\circ} \mathrm{C}$, several OMPs responded by either increasing or decreasing their expression. To avoid technical errors, several measures were taken to ensure that the observed upregulation or down-regulation of OMPs expressed at different temperatures was due only to temperature and not to different amounts of bacterial cells obtained due to different growth conditions. Before the extraction procedure, the concentration of bacterial cells at different growth conditions was normalized to $\mathrm{OD}_{600} 1.8$, based on the growth curve analysis and total bacteria count performed. Furthermore, the same quantities of OMPs were used for analysis of the ATCC and SH057 strains expressed at 37, 38.5 , and $40^{\circ} \mathrm{C}$. The protein extraction at all three temperatures was repeated at least twice to ensure reproducibility and that consistent protein profiles were seen.

A prominent increase in expression of the $18.4 \mathrm{kDa}$ protein was observed at $40^{\circ} \mathrm{C}$ in both strains, and overall, most of OMPs in clinical isolate the clinical OMPs shown increased expression at higher temperature at $40^{\circ} \mathrm{C}$. This increase in protein expression at higher temperature seems to be an immediate response to stress; it might serve as a protective or survival mechanism by making as much of the essential proteins as possible under adverse conditions to ensure cell growth [19]. These proteins must be important for cell survival because they were expressed more during heat stress. A similar comparative study at different temperatures was conducted in China to investigate the protein expression profile of S. flexneri at 30 and $37^{\circ} \mathrm{C}$. At $37^{\circ} \mathrm{C}$ the expressions of most of the virulencerelated proteins were up-regulated, including IpaA, IpaB, IpaC, and IpaD [20]. In our study, temperatures higher than $37^{\circ} \mathrm{C}$ were chosen to investigate the proteome profile of the bacteria during enteric infection, as patients infected with Shigella spp. usually have a low to medium grade fever ranging from 38 to $40^{\circ} \mathrm{C}$.

Protein expression at $40^{\circ} \mathrm{C}$ might be related to the virulence of the pathogen. Bacteria possess specific sensors that respond to stimuli from their new environment, which enable them to express the virulence factor only when required [21]. There are broad ranges of stimuli that bacteria sense and to which they respond. These stimuli include changes in $\mathrm{pH}, \mathrm{PO} 2$, osmolarity, and temperature. For example, in Vibrio cholerae, activation of virulence factors by Tox $\mathrm{R}$, a virulence regulon, is influenced by external stimuli such as temperature, osmolarity, and $\mathrm{pH}$. Several previous studies described the expression of virulence genes in bacteria in response to temperature changes. These include expression of the regulatory gene virF in Yersinia spp. that controls the expression of the OMP Yop, which is related to virulence of the pathogen, and the regulatory gene prfA in $L$. monocytogens that regulates the expression of listeriolysin, which is a virulence factor that helps the survival of the bacterium $[22,23]$.

In the ATCC strain, the expression profiles of most of the proteins did not change with increasing temperature. The maintenance of a constant expression level of some proteins at 38.5 and $40^{\circ} \mathrm{C}$ may indicate that either they lack a role in the survival and virulence of the organism 
Table 1 Overall expression of OMPs present in S. flexneri ATCC12022 and the clinical isolate $\mathrm{SH} 057$ at $37^{\circ} \mathrm{C}, 38.5^{\circ} \mathrm{C}$, and $40^{\circ} \mathrm{C}$

\begin{tabular}{|c|c|c|c|c|c|c|c|}
\hline \multirow[t]{2}{*}{ Band no. } & \multirow[t]{2}{*}{ Molecular weight (kDa) } & \multicolumn{3}{|c|}{ ATCC 12022} & \multicolumn{3}{|c|}{ SH057 } \\
\hline & & $\left(37^{\circ} \mathrm{C}\right)$ & $\left(38.5^{\circ} \mathrm{C}\right)$ & $\left(40^{\circ} \mathrm{C}\right)$ & $\left(37^{\circ} \mathrm{C}\right)$ & $\left(38.5^{\circ} \mathrm{C}\right)$ & $\left(40^{\circ} \mathrm{C}\right)$ \\
\hline 1 & 15.1 & $x$ & $x$ & $x$ & $\sqrt{ }$ & $\sqrt{ }$ & $\sqrt{ }$ \\
\hline 2 & 16.2 & $\sqrt{ }$ & $\sqrt{ }$ & $\sqrt{ }$ & $\sqrt{ }$ & $\sqrt{ }$ & $\sqrt{ }$ \\
\hline 3 & 16.6 & $\sqrt{ }$ & $\sqrt{ }$ & $\sqrt{ }$ & $\sqrt{ }$ & $\sqrt{ }$ & $\sqrt{ }$ \\
\hline 4 & 17.0 & $\sqrt{ }$ & $\sqrt{ }$ & $\sqrt{ }$ & $\sqrt{ }$ & $\sqrt{ }$ & $\sqrt{ }$ \\
\hline 5 & 18.4 & $\sqrt{ }$ & $\sqrt{ }$ & $\sqrt{ }$ & $\sqrt{ }$ & $\sqrt{ }$ & $\sqrt{ }$ \\
\hline 6 & 22.3 & $\sqrt{ }$ & $\sqrt{ }$ & $\sqrt{ }$ & $\sqrt{ }$ & $\sqrt{ }$ & $\sqrt{ }$ \\
\hline 7 & 25.6 & $\times$ & $x$ & $\times$ & $\sqrt{ }$ & $\sqrt{ }$ & $\sqrt{ }$ \\
\hline 8 & 27.4 & $\sqrt{ }$ & $\sqrt{ }$ & $\sqrt{ }$ & $\sqrt{ }$ & $\sqrt{ }$ & $\sqrt{ }$ \\
\hline 9 & 29.0 & $\sqrt{ }$ & $\sqrt{ }$ & $\sqrt{ }$ & $\sqrt{ }$ & $\sqrt{ }$ & $\sqrt{ }$ \\
\hline 10 & 30.9 & $\sqrt{ }$ & $\sqrt{ }$ & $\sqrt{ }$ & $\sqrt{ }$ & $\sqrt{ }$ & $\sqrt{ }$ \\
\hline 11 & 33.5 & $\sqrt{ }$ & $\sqrt{ }$ & $\sqrt{ }$ & $\sqrt{ }$ & $\sqrt{ }$ & $\sqrt{ }$ \\
\hline 12 & 35.0 & $\sqrt{ }$ & $\sqrt{ }$ & $\sqrt{ }$ & $\sqrt{ }$ & $\sqrt{ }$ & $\sqrt{ }$ \\
\hline 13 & 37.8 & $\sqrt{ }$ & $\sqrt{ }$ & $\sqrt{ }$ & $\sqrt{ }$ & $\sqrt{ }$ & $\sqrt{ }$ \\
\hline 14 & 46.3 & $\sqrt{ }$ & $\sqrt{ }$ & $\sqrt{ }$ & $\sqrt{ }$ & $\sqrt{ }$ & $\sqrt{ }$ \\
\hline 15 & 52.8 & $\times$ & $\times$ & $\sqrt{ }$ & $\times$ & $\times$ & $\sqrt{ }$ \\
\hline 16 & 54.6 & $\sqrt{ }$ & $\sqrt{ }$ & $\sqrt{ }$ & $\sqrt{ }$ & $\sqrt{ }$ & $\sqrt{ }$ \\
\hline 17 & 57.0 & $\sqrt{ }$ & $\sqrt{ }$ & $\sqrt{ }$ & $\sqrt{ }$ & $\sqrt{ }$ & $\sqrt{ }$ \\
\hline 18 & 63.2 & $\sqrt{ }$ & $\sqrt{ }$ & $\sqrt{ }$ & $\sqrt{ }$ & $\sqrt{ }$ & $\sqrt{ }$ \\
\hline 19 & 74.6 & $x$ & $x$ & $x$ & $\sqrt{ }$ & $\sqrt{ }$ & $\sqrt{ }$ \\
\hline 20 & 76.3 & $\sqrt{ }$ & $\sqrt{ }$ & $\sqrt{ }$ & $x$ & $x$ & $x$ \\
\hline 21 & 85.3 & $x$ & $x$ & $x$ & $\sqrt{ }$ & $\sqrt{ }$ & $\sqrt{ }$ \\
\hline 22 & 88.2 & $x$ & $x$ & $x$ & $\sqrt{ }$ & $\sqrt{ }$ & $\sqrt{ }$ \\
\hline 23 & 95.4 & $\sqrt{ }$ & $\sqrt{ }$ & $\sqrt{ }$ & $x$ & $x$ & $x$ \\
\hline 24 & 100.3 & $\sqrt{ }$ & $\sqrt{ }$ & $\sqrt{ }$ & $\sqrt{ }$ & $\sqrt{ }$ & $\sqrt{ }$ \\
\hline
\end{tabular}

or that the synthesis of these proteins is necessary to protect cells from the detrimental effects of stress stimuli (e.g., increased temperature, exposure to oxygen radicals, or nutritional deficiencies), [24]. Further studies are needed to elucidate the role of these proteins in the virulence and survival of the pathogen.

Dps have been identified in Escherichia coli as a low molecular weight protein that accumulates during the stationary phase and binds to DNA [25]. Moreover, Dps protein was found to be highly up-regulated in $E$. coli cells as temperature increased [26]. Luders et al. [26] reported that the increase in temperature induces the synthesis of more oxygen radicals, and the cells need to protect their cellular components from heat stress. Thus, overexpression of the dps gene is one of the protective mechanisms that is used during heat stress. dps also plays a major role in protecting genomic DNA against oxidative stress [27], nuclease cleavage, UV light, and thermal stress by its ability to bind with DNA to block the stress elements that attack DNA [28]. Halsey et al.
[29] described the role of Dps in oxidative stress resistance and virulence in Salmonella enterica serovar Typhimurium. They demonstrated the ability of Dps to protect Salmonella from oxidative stress during infection, which enhanceed the virulence of the pathogen. In the current study, the increased expression of the 18.4 $\mathrm{kDa}$ protein (which was identified as Dps) at $40^{\circ} \mathrm{C}$ by $S$. flexneri might be an adaptive response of the bacterium to the heat stress environment.

WrbA, which was been studied most extensively in $E$. coli, is member of the highly conserved family of proteins involved in the cellular response to altered redox conditions and to different kinds of stress [30]. It has sequence similarity to proteins involved in quinonereductase activity [31,32]. WrbA protein is also known as TrpR binding protein, due to its ability to co-purify and co-immunoprecipitate with the tryptophan repressor protein TrpR [33]. Recently, Wang et al. [34] demonstrated that WrbA is one of the target proteins for the salicylidene acyl hydrazides, which are compound that can 
Table 2 Expression of OMPs in the ATCC and SH057 strains of S. flexneri at $38.5^{\circ} \mathrm{C}$ and $40^{\circ} \mathrm{C}$ in comparison to that at $37^{\circ} \mathrm{C}$

\begin{tabular}{|c|c|c|c|c|c|}
\hline Band no. & Molecular weight (kDa) & ATCC $12022\left(38.5^{\circ} \mathrm{C}\right)$ & ATCC $12022\left(40^{\circ} \mathrm{C}\right)$ & $\mathrm{SH} 057\left(38.5^{\circ} \mathrm{C}\right)$ & $\mathrm{SH} 057\left(40^{\circ} \mathrm{C}\right)$ \\
\hline 1 & 15.1 & $x$ & $x$ & $\downarrow$ & $\uparrow$ \\
\hline 2 & 16.2 & $\rightarrow$ & $\rightarrow$ & $\downarrow$ & $\rightarrow$ \\
\hline 3 & 16.6 & $\rightarrow$ & $\rightarrow$ & $\rightarrow$ & $\uparrow$ \\
\hline 4 & 17.0 & $\rightarrow$ & $\rightarrow$ & $\rightarrow$ & $\uparrow$ \\
\hline 5 & 18.4 & $\rightarrow$ & $\downarrow$ & $\rightarrow$ & $\uparrow$ \\
\hline 6 & 22.3 & $\rightarrow$ & $\rightarrow$ & $\rightarrow$ & $\uparrow$ \\
\hline 7 & 25.6 & $x$ & $x$ & $\downarrow$ & $\uparrow$ \\
\hline 8 & 27.4 & $\rightarrow$ & $\rightarrow$ & $\rightarrow$ & $\rightarrow$ \\
\hline 9 & 29.0 & $\rightarrow$ & $\rightarrow$ & $\rightarrow$ & $\rightarrow$ \\
\hline 10 & 30.9 & $\rightarrow$ & $\rightarrow$ & $\rightarrow$ & $\uparrow$ \\
\hline 11 & 33.5 & $\rightarrow$ & $\rightarrow$ & $\rightarrow$ & $\uparrow$ \\
\hline 12 & 35.0 & $\rightarrow$ & $\rightarrow$ & $\rightarrow$ & $\uparrow$ \\
\hline 13 & 37.8 & $\rightarrow$ & $\rightarrow$ & $\rightarrow$ & $\uparrow$ \\
\hline 14 & 46.3 & $\rightarrow$ & $\downarrow$ & $\rightarrow$ & $\uparrow$ \\
\hline 15 & 54.6 & $\rightarrow$ & $\rightarrow$ & $\rightarrow$ & $\uparrow$ \\
\hline 16 & 57.0 & $\rightarrow$ & $\downarrow$ & $\downarrow$ & $\uparrow$ \\
\hline 17 & 63.2 & $\rightarrow$ & $\rightarrow$ & $\downarrow$ & $\rightarrow$ \\
\hline 18 & 74.6 & $x$ & $x$ & $\rightarrow$ & $\uparrow$ \\
\hline 19 & 76.3 & $\rightarrow$ & $\rightarrow$ & $x$ & $x$ \\
\hline 20 & 85.3 & $x$ & $x$ & $\downarrow$ & $\rightarrow$ \\
\hline 21 & 88.2 & $x$ & $x$ & $\rightarrow$ & $\uparrow$ \\
\hline 22 & 95.4 & $\rightarrow$ & $\rightarrow$ & $x$ & $x$ \\
\hline 23 & 100.3 & $\rightarrow$ & $\uparrow$ & $\rightarrow$ & $\uparrow$ \\
\hline
\end{tabular}

$\uparrow$ Increased expression of protein.

$\downarrow$ Decreased expression of protein.

$\rightarrow$ Same level expression of protein.

$\mathrm{x}$ : No protein band seen in one of the temperature.

block the virulence of many Gram negative pathogens. Furthermore, Wang et al. reported that WrbA also contributed to the normal regulation and expression of virulence factors, especially the Type 3 secretion system and the bacterial flagella.

PepA is a member of the leucylaminopeptidase family of metallopeptidases [35]. In E. coli, PepA has been shown to be an active leucineaminopeptidase [36] that plays an important role in protein degradation and metabolism of biologically active peptides [37]. Luders et al. demonstrated that several enzymes involved in amino acid biosynthesis were up-regulated in $E$. coli cells as temperature increased, including PepA [26]. PepA was reported to be a strong thermostable protein that is able to degrade proteins [38]. In the current study, many proteins were synthesized and degraded by the bacterial cells when they were exposed to high temperatures to adapt the stress conditions. Thus, the up-regulation of PepA at $40^{\circ} \mathrm{C}$ seen in both strains likely allowed the bacterial cells to synthesize or degrade new proteins in order to adapt to the heat stress environment.
In this study, the proteome profiles of $S$. flexneri cells grown at $37,38.5$, and $40^{\circ} \mathrm{C}$ were analysed to determine the expression levels of OMPs. The overexpression of certain proteins $(18.4,25.6$, and $57.0 \mathrm{kDa})$ when cells were exposed to higher temperatures likely was the pathogen's strategy to regulate expression of virulencerelated proteins. These proteins were identified by mass spectrometry as being HSPs (Dps and PepA) and a virulence-associated protein (WrbA). This is the first report describing the occurrence of these temperatureregulated proteins in S. flexneri. Further studies are needed to elucidate the role of these proteins in the survival and virulence of the organism at higher body temperatures during infection.

\section{Competing interests}

The authors declare that they have no competing interests.

\section{Authors' contributions}

$\mathrm{HH}$ carried out the experiments and drafted the manuscript. Al participated in the acquisition of funding and in study design. KBS participated in the acquisition of funding and coordination and monitoring of research. 
Both $\mathrm{Al}$ and KBS also edited the manuscript. All authors have read and approved the final manuscript.

\section{Acknowledgements}

This research was supported by a Research University Cluster Grant (1001/ PSKBP/8630012) titled "Molecular approaches to fundamental studies on biomarkers and development of sustainable rapid nanobiodiagnostics to enteric diseases for low resource settings" (2011-2013). We gratefully acknowledge the Institute for Postgraduate Studies, Universiti Sains Malaysia, for providing the fellowship assistance and the Department of Medical Microbiology and Parasitology, School of Medical Sciences, Universiti Sains Malaysia, for providing facilities and specimens.

\section{Author details}

'Department of Medical Microbiology \& Parasitology, School of Medical Sciences, Health Campus, Universiti Sains Malaysia, 16150 Kubang Kerian, Kelantan, Malaysia. ${ }^{2}$ Institute for Research in Molecular Medicine (INFORMM), Universiti Sains Malaysia, 16150 Kubang Kerian, Kelantan, Malaysia. ${ }^{3}$ Islamic Science Institute, Islamic Science University of Malaysia, 71800 Nilai, Negeri Sembilan, Malaysia.

Received: 30 October 2013 Accepted: 18 November 2013 Published: 11 December 2013

\section{References}

1. Peng X, Luo W, Zhang J, Wang S, Lin S: Rapid detection of Shigella species in environmental sewage by an immunocapture PCR with universal primers. Appl Environ Microbiol 2002, 68(5):2580-2583.

2. WHO, Weekly Epidemiological Report: Shigellosis: disease burden, epidemiology and case management. Wkly Epidemiol Rec 2005, 80(11):94-99.

3. Banga Singh KK, Ojha SC, Deris ZZ, Rahman RA: A 9-year study of shigellosis in Northeast Malaysia: antimicrobial susceptibility and shifting species dominance. Z Gesundh Wiss 2011, 19(3):231-236.

4. Torres AG: Current aspects of Shigella pathogenesis. Rev Latinoam Microbiol 2004, 46(3-4):89-97.

5. Hale TL, Formal SB: Pathogenesis of Shigella infections. Path Immunol Res 1987, 6:117-127.

6. Bennish ML, Wojtyniak BJ: Mortality due to shigellosis: community and hospital data. Rev Infect Dis 1991, 13(Suppl 4):S245-S251.

7. Ashkenazi S: Shigella infections in children: new insights. Semin Pediatr Infect Dis 2004, 15(4):246-252.

8. Struelens MJ, Patte D, Kabir I, Salam A, Nath SK, Butler T: Shigella septicemia: prevalence, presentation, risk factors, and outcome. J Infect Dis 1985, 152(4):784-790.

9. Heyking AK, Mclnintosh JJ: Shigella flexneri bacteraemia: an infrequently documented complication of shigellosis. Clin Microbiol News/ 1997, 19(21):166-167.

10. Jyothisri K, Deepak $V$, Rajeswari MR: Purification and characterization of a major $40 \mathrm{kDa}$ outer membrane protein of Acinetobacter baumannii. FEBS Lett 1999, 443(1):57-60.

11. Isibasi A, Ortiz V, Vargas M, Paniagua J, Gonzalez C, Moreno J, Kumate J: Protection against Salmonella typhi infection in mice after immunization with outer membrane proteins isolated from Salmonella typhi 9,12, d, Vi. Infect Immun 1988, 56(11):2953-2959.

12. Guiney DG: Regulation of bacterial virulence gene expression by the host environment. J Clin Invest 1997, 99(4):565-569.

13. Hale TL: Genetic basis of virulence in Shigella species. Microbiol Rev 1991, 55(2):206-224

14. Ellis RJ: Stress proteins as molecular chperons. In Stress Proteins in Medicine. 1st edition. Edited by Eden W, Young DB. New york: CRC Press; 1996:592.

15. Lathigra RB, Butcher PD, Garbe TR, Young DB: Heat shock proteins as virulence factors of pathogens. Curr Top Microbiol Immunol 1991, 167:125-143.

16. Hartman AB, Powell CJ, Schultz CL, Oaks EV, Eckels KH: Small-animal model to measure efficacy and immunogenicity of Shigella vaccine strains. Infect Immun 1991, 59(11):4075-4083.

17. Ismail A, Hai OK, Kader ZA: Demonstration of an antigenic protein specific for Salmonella typhi. Biochem Biophys Res Commun 1991, 181(1):301-305.

18. Lory S, Tai PC: Biochemical ad genetic aspects of Pseudomonas aeruginosa virulence. Curr Top Microbiol Immunol 1984, 118:53-69.

19. Mattson MP: Hormesis and disease resistance: activation of cellular stress response pathways. Hum Exp Toxicol 2008, 27(2):155-162.
20. Zhu L, Zhao G, Stein R, Zheng X, Hu W, Shang N, Bu X, Liu X, Wang J, Feng E, Wang B, Zhang X, Ye Q, Huang P, Zeng M, Wang H: The proteome of Shigella flexneri $2 \mathrm{a} 2457 \mathrm{~T}$ grown at 30 and $37^{\circ} \mathrm{C}$. Mol Cell Proteomics 2010, 9(6):1209-1220.

21. Gross R, Arico B, Rappuoli R: Families of bacterial signal-transducing proteins. Mol Microbiol 1989, 3(11):1661-1667.

22. Leimeister-Wachter M, Haffner C, Domann E, Goebel W, Chakraborty T: Identification of a gene that positively regulates expression of listeriolysin, the major virulence factor of listeria monocytogenes. Proc Natl Acad Sci U S A 1990, 87(21):8336-8340.

23. Maurelli AT: Temperature regulation of virulence genes in pathogenic bacteria: a general strategy for human pathogens? Microb Pathog 1989, 7(1):1-10

24. Fulda S: Cell death and survival signaling in oncogenesis. Klin Padiatr 2010, 222(6):340-400.

25. Almiron M, Link AJ, Furlong D, Kolter R: A novel DNA-binding protein with regulatory and protective roles in starved Escherichia coli. Genes Dev 1992, 6(12B):2646-2654.

26. Luders S, Fallet C, Franco-Lara E: Proteome analysis of the Escherichia coli heat shock response under steady-state conditions. Proteome Sci 2009, 7:36.

27. Martinez A, Kolter R: Protection of DNA during oxidative stress by the nonspecific DNA-binding protein Dps. J Bacterio/ 1997, 179(16):5188-5194.

28. Nair S, Finkel SE: Dps protects cells against multiple stresses during stationary phase. J Bacteriol 2004, 186(13):4192-4198.

29. Halsey TA, Vazquez-Torres A, Gravdahl DJ, Fang FC, Libby SJ: The ferritin-like Dps protein is required for Salmonella enterica serovar Typhimurium oxidative stress resistance and virulence. Infect Immun 2004, 72(2):1155-1158.

30. Grandori R, Carey J: Six new candidate members of the alpha/beta twisted open-sheet family detected by sequence similarity to flavodoxin. Protein Sci 1994, 3(12):2185-2193.

31. Laskowski MJ, Dreher KA, Gehring MA, Abel S, Gensler AL, Sussex IM: FQR1, a novel primary auxin-response gene, encodes a flavin mononucleotidebinding quinone reductase. Plant Physiol 2002, 128(2):578-590.

32. Daher BS, Venancio EJ, De Freitas SM, Bao SN, Vianney PV, Andrade RV, Dantas AS, Soares CM, Silva-Pereira I, Felipe MS: The highly expressed yeast gene pby20 from Paracoccidioides brasiliensis encodes a flavodoxin-like protein. Fungal Genet Biol 2005, 42(5):434-4.

33. Yang W, Ni L, Somerville RL: A stationary-phase protein of Escherichia coli that affects the mode of association between the trp repressor protein and operator-bearing DNA. Proc Natl Acad Sci U S A 1993, 90(12):5796-5800.

34. Wang D, Zetterstrom CE, Gabrielsen M, Beckham KS, Tree JJ, Macdonald SE, Byron O, Mitchell TJ, Gally DL, Herzyk P, Mahajan A, Uvell H, Burchmore R, Smith BO, Elofsson M, Roe AJ: Identification of bacterial target proteins for the salicylidene acylhydrazide class of virulence-blocking compounds. J Biol Chem 2011, 286(34):29922-29931.

35. Barrett AJ, Rawlings ND, Woessner JF: Handbook of Proteolytic Enzymes. 3rd edition. San Diego, California: Academic; 1998.

36. Vogt VM: Purification and properties of an aminopeptidase from Escherichia coli. J Biol Chem 1970, 245(18):4760-4769.

37. Burley SK, David PR, Taylor A, Lipscomb WN: Molecular structure of leucine aminopeptidase at 2.7-A resolution. Proc Natl Acad Sci U S A 1990, 87(17):6878-6882.

38. Gonzales T, Robert-Baudouy J: Bacterial aminopeptidases: properties and functions. FEMS Microbiol Rev 1996, 18(4):319-344.

doi:10.1186/1757-4749-5-38

Cite this article as: Harikrishnan et al:: Temperature-regulated expression of outer membrane proteins in Shigella flexneri. Gut Pathogens 2013 5:38. 